Aton-cult. That there are no traces whatever of such influences, but that the Aton-cult is in every respect essentially Egyptian, the facts set forth in this article must have made perfectly clear. However, it is possible that Okhnatōn had foreign blood in his veins, for Prof. Elliot Smith maintains that his maternal grandfather, Iuyu, is distinctly non-Egyptian in type. To this dash of foreign blood, therefore, may well be due the originality clearly displayed by Ökhnaton in the particular expression which he gave to a certain trend of religious thought prevailing among his contemporaries.

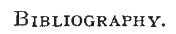

J. H. Breasted, "Development of Religion and Thought in Ancient Egypt," London, I912, pp. 312-343.

By the same author, "A History of Egypt," London, I906, pp. 355-395. A. M. Blackman, "A Study of the Liturgy celebrated in the Temple of the Aton at El-Amarna," in Recueil d'etudes égyptologiques dédié à la mémoire de Jean-François Champollion, Paris, I922, pp. 505-527. By the same author, the article "Worship" (Egyptian) in Hastings' "Encyclopædia of Religion and Ethics," \$ iv.

A. Erman, "A Handbook of Egyptian Religion," translated by A. S. Griffith, London, I9o7, pp, 57-70.

Griffith, London, 1907, pp. 57-70. Auflage, Berlin, r9o9, pp. 7 I-84. Auflage, Berlin, "99, pp. $71-84$.
L. Borchardt, "Aus der Arbeit an den Funden von Tell el-Amarna," in
Mitteilungen der Deutschen Orient-Gesellschaft zu Berlin, March I917, No. 57. N. de G. Davies, "The Rock Tombs of El-Amarna," in six parts, London, I903-1908.

H. Schäfer, "Die frühesten Bildnisse König Amenophis des IV. Ein Beitrag zur Entstehung der Kunst von Tell El-Amarna," in Amtliche Berichte aus den preuszischen Kunstsammlungen, xl. Jahrgang, Nr. Io, Juli I919, pp. 2 I I- 230 .

By the same author, "Die Anfänge der Reformation Amenophis des IV..," in Sitzungsberichte der preussischen Akademie der Wissenschaften, I919, xxvi.

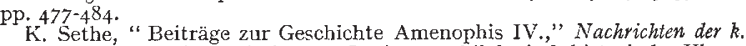
Gesellschaft der Wissenschaften zu Göttingen, philologisch-historische Klasse, I $92 \mathrm{I}$, $\mathrm{pp}$. IOI-I 30 .

C. Siemens and $r_{\text {. }}$. Auer, "Koenig Echnaton in El-Amarna," Leipzig, 1922. A. Weigall, "The Life and Times of Akhnaton, Pharaoh of Egypt," new and revised edition, London, 1923.

\title{
Scientific Investigation of the Whaling Problem.
}

\section{By Sir Sidney F. Harmer, K.B.E., F.R.S.}

$\mathrm{T}^{\mathrm{H}}$ HE Colonial Office has recently announced that the Discovery has been purchased by the Crown Agents for the Colonies, on behalf of the Falkland Islands, for employment in researches, principally on whaling, off South Georgia and the South Shetlands. The Discovery was built for Capt. R. F. Scott's first Antarctic Expedition (I90r-I904). She is a strong wooden vessel of about 700 tons register, and she has been chosen with special reference to her suitability for ice-work.

Subantarctic whaling commenced at the end of 1904 , at a time when the industry was regarded as almost obsolete, owing to the exhaustion of the old whaling fields. It increased with so much rapidity that more than 10,000 whales were caught during the season I9II-I2. At first concerned almost exclusively with the humpback, the operations are at present supported almost entirely at the expense of the much larger fin whale and blue whale. Humpbacks showed an alarming decline in numbers after the rgr I-I 2 season, though they have made some recovery during the last two whaling seasons.

It should be realised that modern whaling is carried on by comparatively small steam vessels fitted with appliances for the capture of the whales, the products of which are worked up by factories on shore or by larger steamers, the floating factories. In either case, suitable harbours are required as bases, and the most favourable localities at present known are South Georgia, which lies to the east of the Falkland Islands, and the South Shetlands, which are farther to the south-west. These islands are dependencies of the Falkland Islands, and are accordingly under British jurisdiction.

As the result of several memoranda which were prepared in 1917 by Mr. E. R. Darnley, of the Colonial Office, an Interdepartmental Committee on research and development in the dependencies of the Falkland Islands was appointed by the Secretary of State for the Colonies in I9I8; and its report (Cmd. 657) was published in r.920. The report contained a number of recommendations with regard to the investigations which were required ; and the purchase of the Discovery is the first practical result of these suggestions. It should be mentioned that an earlier Anglo-Swedish scheme for the investigation of the same problems was abandoned on the outbreak of war in rgr4.
The object of the projected voyages is to obtain scientific evidence bearing on the whaling problem generally, with the view of ascertaining to what extent protective measures are required. It has to be determined, in the first instance, what are the species of whales which are being hunted. Although known to the whalers as humpback, fin whale, and blue whale, it is uncertain whether these are identical with the northern whales known by the same names. Whales are migratory animals, and there can be no reasonable doubt that they visit the Antarctic Ocean in order to profit by the rich food-supply of its waters, and that they afterwards depart, fatter than when they arrived, to warmer waters, which are probably visited for breeding purposes. More definite information is required with regard to these migrations, and it is hoped that it may be possible to obtain direct evidence by a system of marking individual whales.

The period of gestation, the seasons when pairing and birth take place, and the rate of growth after birth all need further study. The plankton requires investigation, in view of the dependence of the whales on it for food; while the temperature of the water, with other hydrographical questions, has to be studied, in order to ascertain how far these factors influence the movements of whales. There is already some reason to suppose that the position of the northern edge of the Antarctic ice is a factor which is correlated with the success or failure of a season's working. If the summer is relatively warm the ice will be too far to the south and the whales will probably be too distant from the base. If the summer is cold the whales will be too much to the north. It may be anticipated that there is an optimum position for the ice which brings the main stream of whales to the neighbourhood of the whaling stations.

Although whalebone whales all feed on plankton, individual species are known to have a preference for one kind of plankton rather than another. In most localities the humpback consumes a considerable amount of fish, while the blue whale is said to feed exclusively on Crustacea. The distribution and the seasonal occurrence of various kinds of plankton, and the examination of the stomach-contents of whales, are matters with which the expedition will certainly have to deal; and the results may prove to have a 
distinct bearing on the question why each species of whale differs from the others in its seasonal occurrence. The abundance of whale-food is dependent on conditions favourable for the growth of diatoms and other chlorophyll-containing organisms; and in this connexion may be mentioned Mr. A. G. Bennett's interesting observation that the skin of certain whales is covered by a film composed of innumerable diatoms. The evidence is in favour of the view that this skin-film is not present on thin individuals which have recently come down from the north, but that it develops during the stay of the whales in Antarctic waters. The study of the film and perhaps of whale-parasites may prove to be capable of giving important information with regard to migrations.

For many years the Norwegians have taken the leading place in the whaling industry, and they have large interests in Antarctic whaling. It is thus natural that they should feel anxiety with regard to the possible results of a protective policy, and this is shown by an article recently published in the Anglo-Norwegian Trade Journal (Vol. 9, No. 98, February). The comments in question were a rejoinder to criticisms of the whaling industry which had appeared in the Morning Post, based on a lecture given by myself, as reported in NATURE. (Vol. r1o, December I6, I922, p. 827). I had pointed out, on the incontrovertible evidence of history, that the operations of whalers in the past have been invariably followed by a depletion of the whaling fields. The Atlantic right whale no longer frequents the Bay of Biscay in numbers sufficient to maintain a whaling industry, nor is the Greenland whale still common in the bays of Spitsbergen, in Davis Straits, or even in the North Pacific. The grey whale disappeared long ago from the lagoons of California, and there is no longer occupation for the hundreds of vessels which left European and American ports annually, in the eighteenth and part of the nineteenth centuries, in pursuit of the Greenland and other right whales and the sperm whale. With these facts in view the least that is required is the adoption of a cautious policy, lest the mistakes of the past should be repeated.
The whaling companies are admittedly interested in the avoidance of extermination, which would mean the closing of their operations, but their advocates have maintained that, in view of the enormous extent of the oceans which are frequented by whales, the activity of hunters in a small area is not likely to produce much effect in reducing their number. It will be seen, however, by consulting a map, that South Georgia and the South Shetlands lie in the region where the Antarctic Ocean is narrowest, and that they are admirably situated to intercept the stream of whales in their circumpolar movements. It would not be surprising if operations at these stations alone were found capable of depleting very seriously the entire stock of Antarctic whales, even if no new stations were to be founded in other localities, as seems likely to happen in Ross Sea, for example. The danger is all the greater, taking into consideration the highly efficient methods of modern whaling.

The acquisition of a sound body of scientific evidence is the object of the expeditions which are being planned by the Colonial Office. Although I do not conceal my personal conviction, as at present informed, that whaling is being conducted on too large a scale, I do not deny that a study of the subject by competent investigators on the spot may lead to a different conclusion. The Trustees of the British Museum have acted in an advisory capacity to the Colonial Office since they first became interested in Antarctic whaling, not long after its inception. I am authorised to state that they do not desire to take up an extreme position in the matter, but that their efforts are directed to the restriction of whaling to an extent which is not inconsistent with the permanent preservation of whales. This is a moderate view, with which it may be hoped that the representatives of the whaling industry will agree in principle. The article to which I have referred virtually admits as much, and the willing co-operation of the whaling companies will be of the greatest value to the expedition. It may be hoped that it will be possible to find a modus vivendi satisfactory to both parties, who are equally interested in preventing the extermination of whales.

\section{Einstein and the Recent Eclipse.}

THE results of the expeditions from Canada and the Lick Observatory to Wallal, Western Australia, for the solar eclipse of last September have now come to hand; and both report in favour of the Einstein shift of starlight. In each case the number of stars measured was very large-exceeding eightythe magnitudes being between the seventh and the tenth. From this it is evident that the exposures were comparatively long, and consequently there would be considerable extension of the corona on the plates, which would obliterate the stars nearest the sun. The measures, however, were sufficiently exact to give a decisive result using the more distant stars. Profs. Campbell and Trumpler measured all their plates in duplicate; the values for the shift at the limb of the sun deduced from the individual plates ranged from $\mathbf{I} \cdot 59^{\prime \prime}$ to $\mathbf{I} \cdot 86^{\prime \prime}$, the mean of all being $\mathrm{I} \cdot 74^{\prime \prime}$, which is only $\circ \cdot \circ \mathrm{I}^{\prime \prime}$ less than Einstein's predicted value.

As Prof. Campbell is well known to have been in no sense predisposed in favour of Einstein's theory, this result, combined with that of Prof. Chant and the mean of the Principe and Sobral results in the I9I9 eclipse, will probably be regarded as setting the question at rest. Prof. Campbell says in his telegram that he considers further work of this kind unnecessary, so that he will attack other problems in the Californian eclipse of next September. There are still the plates taken by the Australian expeditions to be measured. This is to be done at Greenwich; their scale is smaller than that of the Lick Observatory plates, so that probably less weight will attach to them.

The evidence as regards the presence of the shift in the solar spectral lines is now fairly evenly balanced "For" and "Against"; but in any case this test is a less decisive one than the other two, since there are so many known causes of shift of spectral lines, which it is not easy to eliminate completely.

A. C. D. C. 